\title{
Sternal recumbency or suspension by the hind legs immediately after delivery improves respiratory and metabolic adaptation to extra uterine life in newborn calves delivered by caesarean section
}

\author{
Christophe UystePruYsta*, Joost Coghe ${ }^{\mathrm{a}}$, Thierry DorTs ${ }^{\mathrm{a}}$, \\ Natacha HARMEGNIES ${ }^{\mathrm{a}}$, Marie-Hélène Delsemme ${ }^{\mathrm{b}}$, Tatiana ART ${ }^{\mathrm{a}}$, \\ Pierre LEKEUX ${ }^{\mathrm{a}}$
}

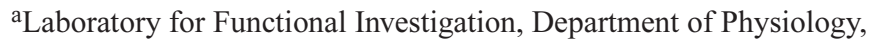
Faculty of Veterinary Medicine, Bât. B42, Sart Tilman, 4000 Liège, University of Liège, Belgium ${ }^{\mathrm{b}}$ Quantitative Methodology, Faculty of Economics, Business and Social Sciences, University of Liège, Belgium
\end{abstract}

(Received 25 October 2001; accepted 28 May 2002)

\begin{abstract}
The aim of this study was to evaluate the effect of body positioning immediately after delivery on respiratory and metabolic adaptation to extra-uterine life in newborn calves. One hundred and one Belgian White and Blue calves were delivered at term by an elective caesarean section and were assigned into three categories according to the body position imposed immediately after umbilical cord rupture: 71 calves were placed in lateral recumbency; 16 calves were placed in sternal recumbency and 14 calves were suspended by the hind legs for less than 90 seconds ( $75 \pm 5 \mathrm{~s}$ ). Following this initial body position, the calves were allowed to move without restraint. They were examined at birth, 5, 15, 30, 45 and 60 minutes, and 2, 3, 6, 12 and 24 hours after birth by the following measurements: physical examination, heart rate, arterial blood gas analysis, pulmonary function tests using the esophageal balloon catheter technique, arterial and venous blood acid-base balance analysis, rectal temperature, jugular venous blood sampling for the determination of blood glucose, plasma lactate and serum cortisol concentrations, haematologic variables and passive immune transfer variables. Body positioning immediately after delivery clearly influenced respiratory and metabolic adaptation to extra-uterine life in term calves delivered by an elective caesarean section. Systematic sternal recumbency and suspension by the hind legs for less than 90 seconds immediately after umbilical cord rupture had a positive functional impact on postnatal pulmonary mechanics and gas exchange and on postnatal correction of mixed acidosis present at birth, contributing in turn to an enhanced passive immune transfer. These two body positions should be encouraged to improve adaptation at birth in healthy term calves delivered by an elective caesarean section. Evaluation of possible side-effects is required before application in severely asphyxiated calves.
\end{abstract}

bovine / neonate / birth / body positioning / physiology

*Correspondence and reprints

Tel.: (32) 436640 30; fax: (32) 436629 35; e-mail: christophe.uystepruyst@belgacom.net 
Résumé - Confiner le veau en décubitus sternal ou le suspendre par les membres postérieurs à la naissance améliore son adaptation respiratoire et métabolique à la vie extra-utérine. L'objectif de cette étude était d'évaluer l'effet du décubitus sternal ou de la suspension systématique par les membres postérieurs immédiatement à la naissance sur l'adaptation respiratoire et métabolique chez le veau nouveau-né sain. Cent et un veaux de race Blanc-Bleu Belge à terme nés par césarienne ont été répartis en trois catégories selon la position dans laquelle ils ont été délibérément placés immédiatement après la rupture du cordon ombilical. La première catégorie comprend les veaux placés en décubitus latéral $(n=71)$; la seconde, ceux placés en décubitus sternal $(n=16)$; et la troisième, les veaux suspendus par les membres postérieurs pendant moins d'une minute trente secondes ( $75 \pm 5 \mathrm{~s})(n=$ 14). Les veaux ont été examinés à la naissance, à l'âge de 5, 15, 30, 45 et 60 minutes, 2, 3, 6, 12 et 24 heures après la naissance au moyen des tests suivants: un examen clinique, une analyse des gaz sanguins, des tests de fonction pulmonaire par la technique du ballonnet œsophagien, une analyse de l'équilibre acido-basique dans le sang artériel et veineux, une prise de température rectale, un prélèvement de sang veineux jugulaire pour la mesure de la glycémie, de la lactatémie, de la cortisolémie, une détermination des paramètres hématologiques et enfin une évaluation de l'immunité passive colostrale. La position dans laquelle le veau est placé immédiatement après la rupture du cordon ombilical a influencé l'adaptation respiratoire et métabolique des veaux au cours des 24 premières heures de vie. Le décubitus sternal systématique ou la suspension systématique par les membres postérieurs pendant moins d'une minute trente secondes ont exercé d'une part, une influence positive sur la mécanique du système respiratoire et sur les échanges gazeux pulmonaires et d'autre part, une correction plus rapide de l'acidose mixte présente à la naissance. Cette dernière a en outre permis un meilleur transfert de l'immunité passive colostrale. Au vu de ces résultats, il convient de recommander ces positions pour améliorer l'adaptation respiratoire et métabolique chez le veau nouveau-né sain et à terme né par césarienne. Il est indispensable de connaître leurs éventuels effets secondaires avant de les appliquer de manière systématique chez les veaux présentant une asphyxie sévère à la naissance.

\section{bovin / nouveau-né / naissance / position corporelle / physiologie}

\section{INTRODUCTION}

In bovine medicine, around $60 \%$ of all perinatal calf mortalities (2-8\%) occur within 24 hours after birth [31, 34]. Perinatal losses occur especially in cases of abnormal parturition [10, 31, 35]: hypoxaemia and uncorrected respiratory and metabolic acidosis following difficult birth are well-known causes that may directly or indirectly lead to death $[10,35,39$, 43].

Perinatal calf losses greatly vary from herd to herd and depend on general herd management practices $[12,15]$.

To reduce perinatal calf deaths and subsequent high economical losses, it is necessary to better define normal physiological changes in healthy calves during adaptation to extra-uterine life and to modify management of the newborn immediately after birth $[1,30]$. Advances in the understanding of the physiology and pathophysiology of the periparturient period in humans as well as in pigs, sheep and horses have resulted in practical benefits such as costeffective and straightforward management strategies which reduce neonatal losses [32, $37,48,49]$.

In human medicine, body positioning affects respiratory function both in adults and neonates with or without respiratory illness. Changing the body position of the newborn baby is a well-known procedure to improve respiratory function and oxygenation and is a determinant risk factor in the sudden infant death syndrome [13].

Postural modifications of metabolic homeostasis have also been reported in early infancy [41].

Substantial elevations in arterial oxygen tension are well correlated with a change 
from lateral to sternal recumbency in neonatal foals as in anaesthetised adult horses $[14,17,23]$.

Recently, changes in variables measuring respiratory function, acid-base balance, some metabolic pathways, as well as changes in haematological and passive immune transfer variables have been assessed during the first 24 hours after delivery in order to describe a successful transition to extra-uterine life in healthy calves [45].

Sternal recumbency and suspension by the hind legs have been recommended $[6$, $18,21,30]$ to resuscitate compromised newborn calves but the efficiency of such procedures has not yet been evaluated, even in healthy newborn calves $[6,10]$.

Therefore, the purpose of this study was to evaluate the effect of body positioning immediately after delivery on respiratory and metabolic adaptation to extra-uterine life in newborn calves.

\section{MATERIALS AND METHODS}

\subsection{Calves and body positioning}

One hundred and one (101) Belgian White and Blue calves, including 54 males $(50.8 \pm 1.0 \mathrm{~kg})$ and 47 females $(49.0 \pm 1.1 \mathrm{~kg})$, delivered at term $(283 \pm 1 \mathrm{~d})$ by an elective caesarean section were studied.

Calves were grouped into 3 categories according to the body position imposed immediately after umbilical cord rupture: 71 calves were placed in lateral recumbency and allowed to reach spontaneous sternal recumbency, 16 calves were manually placed in sternal recumbency, and 14 calves were suspended by the hind legs using calving ropes and after suspension, were placed in lateral recumbency and allowed to reach spontaneous sternal recumbency. Suspension was stopped once the first defense movement was observed.
After initial body positioning at birth, all calves were allowed to move without any restraint.

\subsection{Experimental protocol}

The calves were investigated $5,15,30$, 45 and 60 minutes, and 2, 3, 6, 12 and 24 hours after birth. At each of these time points, the following examinations were carried out:

- physical examination;

- cardio-respiratory function: heart rate (mHR), arterial blood gas analyses and pulmonary function tests using the esophageal balloon catheter technique;

- metabolic pathways: rectal temperature (RT), arterial and venous acid-base balance variables, plasma lactate $(\mathrm{L})$, blood glucose $(G)$, serum cortisol concentrations (C);

- haematological variables: red blood cell count (RBC), total haemoglobin concentration $(\mathrm{Hb})$ and haematocrit $(\mathrm{Ht})$;

- passive immune transfer variables: serum total protein (TP) and $\beta_{2} \gamma$ globulin $\left(\beta_{2} \gamma\right)$ concentrations.

An additional sample of venous and arterial blood was drawn from the umbilical cord (T0) to determine blood gases and acid-base balance variables. L, G, C, RBC, $\mathrm{Hb}$ and $\mathrm{Ht}$ as well as TP and $\beta_{2} \gamma$ were only measured 5 and 60 minutes, and 6 and 24 hours after birth.

After delivery, the calves were housed in a calving pen with standardised ambient conditions. Calves were neither tranquillised nor sedated. All calves ingested $40 \mathrm{~mL} \cdot \mathrm{kg}^{-1}$ of body weight of a colostrum that contained $80 \mathrm{~g} \cdot \mathrm{L}^{-1}$ total protein in two meals within the first 6 hours after delivery (the first feeding was at 1 hour and the second at 6 hours) [50]. 


\subsection{Physical variables}

Calves were considered to be healthy and free of macroscopic congenital defects after a physical examination performed within 5 minutes after birth. The time interval between birth and sternal recumbency (T-SR) without human aid was recorded and used to evaluate the calves' vitality [40]. The duration of the suspension, i.e. from umbilical cord rupture to lateral recumbency on the ground, was recorded.

Fluid expulsed from the mouth and nose during suspension was collected and the quantity was determined.

\subsubsection{Cardio-respiratory function variables}

\subsubsection{Heart rate}

Heart auscultation was performed to assess heart rate (mHR).

\subsubsection{Arterial blood gas analyses}

Arterial blood samples were withdrawn anaerobically from the Art. axillaris/subclavia [16] in a $2 \mathrm{~mL}$ heparinised syringe. They were stored in ice and analysed within 5 minutes by a blood gas analyser (AVL 995, VEL, Leuven, Belgium) for blood gas tensions [arterial partial pressure in oxygen $\left(\mathrm{PaO}_{2}\right)$, arterial partial pressure in carbon dioxide $\left.\left(\mathrm{PaCO}_{2}\right)\right]$. These values were corrected for rectal temperature [22]. The analyser automatically calculated the alveolo-arterial gradient $\left(\mathrm{A}-\mathrm{aDO}_{2}\right)$ by subtracting $\mathrm{PaO}_{2}$ from the alveolar partial pressure of oxygen $\left(\mathrm{PAO}_{2}\right) \cdot \mathrm{PAO}_{2}$ was calculated from the following equation:

$$
\mathrm{PAO}_{2}=\left(\mathrm{BP}-\mathrm{PH}_{2} \mathrm{O}\right) . \mathrm{FIO}_{2}-\left(\mathrm{PaCO}_{2} / \mathrm{RQ}\right)
$$

where BP is the ambient barometric pressure (automatically measured by the blood gas analyser), $\mathrm{PH}_{2} \mathrm{O}$ the water vapour pressure (calculated as a function of body temperature), $\mathrm{FIO}_{2}$, the fractional concentration of oxygen in inspired air (0.21). The respi- ratory exchange ratio values (RQ) previously determined by Vermorel et al. [46] for newborn calves were used for calculations: $\mathrm{RQ}=0.80$ for blood gas analyses performed before 12 hours old and RQ $=0.76$ at 18 and 24 hours old. The analyser was calibrated every three hours with a two-point calibration using certified gas mixtures for oxygen and carbon dioxide partial pressures.

\subsubsection{Pulmonary function tests}

Pulmonary function tests were performed using the esophageal balloon catheter technique [25].

Respiratory airflow was measured using a heated Fleisch pneumotachograph $\left(\mathrm{n}^{\mathrm{r}} 2\right.$ or 3) mounted on a tight-fitting face mask and coupled to a differential pressure transducer (Validyne DP 45-14, Validyne Engineering) with two identical catheters. Pleural pressure changes were measured with an esophageal balloon catheter made from a condom sealed over the end of a polyethylene tube (length: $170 \mathrm{~cm}$, ID: $2 \mathrm{~mm}$, OD: $3 \mathrm{~mm}$ ) with a wide bore distal end (20 holes equally distributed over $10 \mathrm{~cm}$ ) in the part covered by the condom.

All flow and pressure signals were fed into a computer provided with the $\mathrm{Po} \mathrm{Ne}$ Mah system (Gould Instrument Systems), which derived ventilatory [respiratory rate $(\mathrm{RR})$, tidal volume $\left(\mathrm{V}_{\mathrm{T}}\right)$, minute volume $\left(\mathrm{V}_{\mathrm{E}}\right)$ ] and mechanical (total pulmonary resistance $\left(\mathrm{R}_{\mathrm{L}}\right)$, dynamic lung compliance $\left(C_{\text {Ldyn }}\right)$ ' values on each artefact free respiratory cycle. For statistical analysis, values of 25 regular respiratory cycles were recorded and averaged.

Measurements were performed on calves in the sternal position during the first two hours after birth and in the standing position from 3 to 24 hours, with standardised head and neck positions [26]. 


\subsection{Metabolic variables}

\subsubsection{Rectal temperature}

Rectal temperature (RT) was measured using a digital thermometer $\left(\operatorname{Hartmann}^{\circledR}\right)$.

\subsubsection{Acid-base balance}

Arterial and venous acid-base balance variables (arterial $\mathrm{pH}(\mathrm{apH})$, arterial bicarbonate concentration $\left(\mathrm{aHCO}_{3}^{-}\right)$, arterial base excess $(\mathrm{aBE})$; venous $\mathrm{pH}(\mathrm{vpH})$, venous bicarbonate concentration $\left(\mathrm{vHCO}_{3}^{-}\right)$ and venous base excess (vBE)) were calculated by the blood gas analyser (AVL 995, VEL, Leuven, Belgium) on arterial and venous blood samples. The analyser was calibrated every three hours with a two-point calibration using buffers.

\subsubsection{Lactate}

A droplet of whole jugular venous blood was deposed on the reactive strip of a portable lactate analyser (Accusport ${ }^{\circledR}$, Boehringer Mannheim) for determination of plasma lactate concentration $\left(\mathrm{L}\right.$, in $\left.\mathrm{mmol} \cdot \mathrm{L}^{-1}\right)$. The portable analyser was used according to recommendations made by Coghe for the bovine species [7].

\subsubsection{Glucose}

A droplet of whole jugular venous blood was deposed on the reactive strip of a portable blood glucose meter (One Touch Profile $^{\circledR}$, LifeScan Inc, Mountain View, CA, USA) for determination of blood glucose concentration $\left(\mathrm{G}\right.$, in $\left.\mathrm{mg} \cdot \mathrm{dL}^{-1}\right)$. The portable analyser was used according to recommendations made by Roeder for the bovine species [36].

\subsubsection{Cortisol}

An aliquot of the jugular blood sample was added to a dry tube. Blood tubes were centrifuged (10' at $1500 \mathrm{~g}$ ) immediately after sampling and the serum was stored at $4{ }^{\circ} \mathrm{C}$ until serum cortisol concentration
$\left(\mathrm{C}\right.$, in $\left.\mathrm{ng} \cdot \mathrm{mL}^{-1}\right)$ was measured by a doubleantibody radioimmunoassay technique according to Massip et al. [29].

\subsection{Haemotological variables}

\subsubsection{Complete Blood Count}

Another aliquot of the jugular blood sample was added to an EDTA-K $\mathrm{K}_{3}$ containing tube and was stored at $4{ }^{\circ} \mathrm{C}$ and analysis was performed within four hours after sampling. Red Blood Cell count ( $\mathrm{RBC}$, in $10^{12}$ cells $\left.\cdot \mathrm{L}^{-1}\right)$ and total haemoglobin concentration $\left(\mathrm{Hb}, \mathrm{g} \cdot \mathrm{dL}^{-1}\right)$ were determined using the Abbott Cell-dyn ${ }^{\circledR} 3500$ automated haematology analyser (Abbott, Diagnostics Division, Santa Clara, CA, USA). Haematocrit $(\mathrm{Ht}, \%)$ was calculated with the same system.

\subsection{Immune passive transfer variables}

\subsubsection{Serum total protein and $\beta_{2} \gamma$ globulin concentrations}

Another aliquot of jugular venous blood was added to a dry tube. Blood tubes were centrifuged (10' at $1500 \mathrm{~g}$ ) immediately after sampling and serum was stored at $4{ }^{\circ} \mathrm{C}$ until serum total protein concentration (TP, in $\mathrm{g} \cdot \mathrm{L}^{-1}$ ) was measured by the colorimetric Biuret method (Total Protein Merckotest 1.03327.0001, Merck Diagnostica, Darmstadt, Germany). The $\beta_{2} \gamma$ globulin proteinic subfraction $\left(\beta_{2} \gamma \%\right.$, in $\%$ of TP) was isolated using a titan gel electrophoretic analysis (Titan gel electrophoresis kit 3041, Elena Laboratories, UK). The $\beta_{2} \gamma$ globulin concentration $\left(\beta_{2} \gamma\right.$, in $\mathrm{g} \cdot \mathrm{L}^{-1}$ ) was calculated by multiplying the $\beta_{2} \gamma \%$ by TP.

\subsection{Statistical analysis}

A continuous auto regressive moving average model for unequally spaced repeated measurements [20] was used to evaluate the changes in the selected physiological 
variables during the first 24 hours of life in the calves. Profile equations for each measured variable were developed to describe how these variables vary over time (age of the calf). The Akaike criterion [2] has been computed for the model with and without the covariate factor tested, i.e. body positioning after delivery, taking into account risk-factors with a significant effect. Deviances were computed, allowing standard chi-square tests to be applied to evaluate the effects of time and body positions on the selected physiological variables. Appropriate estimates and standard errors were calculated, allowing standard t-tests to be applied for comparison of the 3 categories of body position.

Responses were modelled with an autoregression of order one [AR(1)] to reflect the fact that observations made more closely in time may be more closely related. Moreover, if relevant, individuals were seen as random effects with an arbitrary between subject covariance matrix.

In order to evaluate the effect of duration of suspension on the response variables, duration was considered as a covariate factor and was tested independently in the subpopulation of the calves suspended by the hind legs. The Akaike criterion [2] has been computed for the model with and without suspension time. Deviances were also computed, allowing standard chisquare tests to be applied.

A one-way ANOVA was used to evaluate the effect of body position on T-SR. The effect of duration of suspension on fluid collected was evaluated by a regression analysis. The significant difference of the slope from zero was determined using a two-tailed Student $t$ test.

All data were expressed as mean \pm SEM.

\section{RESULTS}

The time between birth and sternal recumbency was significantly $(p \leq 0.05)$ lower in calves suspended by the hind legs than in calves in lateral recumbency with $2.7 \pm 0.9$ and $3.7 \pm 0.5$ minutes, respectively.

The time courses of aBE, vpH, RR, $\mathrm{V}_{\mathrm{E}}$, $R_{L}, G, L, C$ and Ht were not significantly modified by body position. Conversely, the body position significantly $(p \leq 0.05)$ influenced the time course of $\mathrm{PaO}_{2}, \mathrm{SaO}_{2}$, $\mathrm{PaCO}_{2}, \mathrm{apH}, \mathrm{aHCO}_{3}, \mathrm{AaDO}_{2}, \mathrm{vHCO}_{3}$, vBE, mHR, RT, $\mathrm{V}_{\mathrm{T}}, \mathrm{C}_{\mathrm{Ldyn}}, \beta_{2} \gamma, \mathrm{RBC}, \mathrm{Hb}$ and TP.

The duration of the suspension averaged $75 \pm 5$ seconds and ranged from 40 to 90 seconds. Among the variables that were significantly influenced by body position, the following were also significantly $(p \leq 0.05)$ modified by the duration of the suspension: $\mathrm{PaO}_{2}, \mathrm{SaO}_{2}, \mathrm{vBE}, \mathrm{C}_{\mathrm{Ldyn}}, \mathrm{RBC}$ and $\mathrm{Hb}$. An increase in duration of suspension was accompanied by an increase in $\mathrm{PaO}_{2}, \mathrm{SaO}_{2}$, vBE and $\mathrm{C}_{\mathrm{Ldyn}}$ and by a decrease in $\mathrm{RBC}$ and $\mathrm{Hb}$. $\mathrm{R}_{\mathrm{L}}$ decreased significantly ( $p \leq 0.05)$ when suspension was longer.

Fluid collected tended to increase with an increase in duration of suspension but the relationship was not significant.

From birth to 24 hours, $\mathrm{PaO}_{2}$ increased significantly $(p \leq 0.001)$ with time in the three groups of calves (Fig. 1). Calves in sternal recumbency and those suspended by the hind legs had significantly $(p \leq 0.05)$ higher $\mathrm{PaO}_{2}$ values than calves in lateral recumbency. The postnatal increase in $\mathrm{PaO}_{2}$ was greater in calves in sternal recumbency and suspended by the hind legs than in those in lateral recumbency (Fig. 1).

Changes in $\mathrm{SaO}_{2}$ with time followed a similar trend to that of $\mathrm{PaO}_{2}$ (Fig. 1).

From 5 minutes to 24 hours, there was a significant $(p \leq 0.001)$ and progressive decrease in $\mathrm{PaCO}_{2}$ with time in all calves (Fig. 1). From 5 minutes after birth to 24 hours, $\mathrm{PaCO}_{2}$ values in calves in sternal recumbency and suspended by the hind legs remained significantly $(p \leq 0.05)$ lower than in calves in lateral recumbency. At 

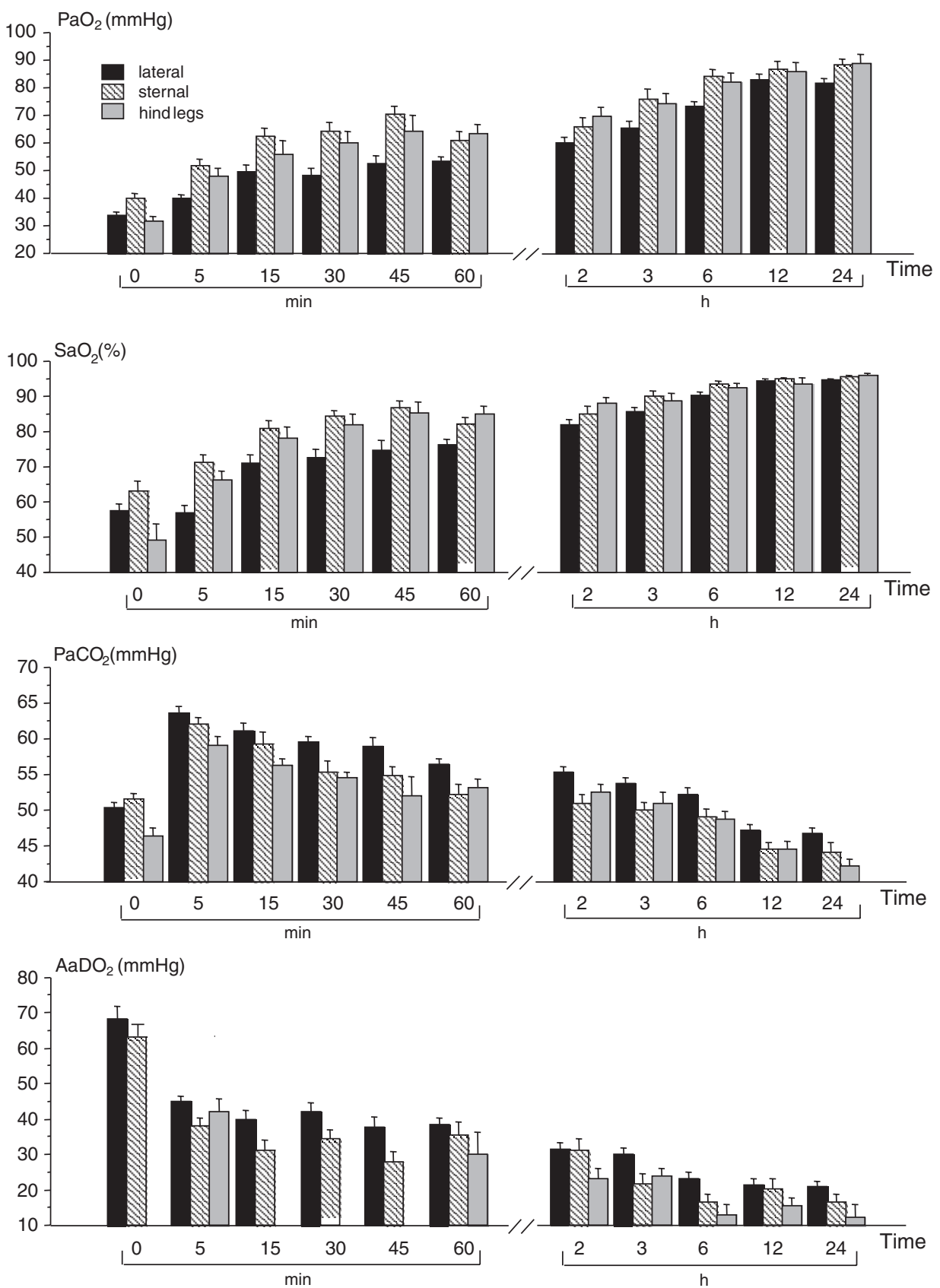

Figure 1. Changes in arterial partial pressure of oxygen $\left(\mathrm{PaO}_{2}\right)$, arterial haemoglobin oxygen saturation $\left(\mathrm{SaO}_{2}\right)$, arterial partial pressure of carbon dioxide $\left(\mathrm{PaCO}_{2}\right)$ and alveolo-arterial difference of oxygen $\left(\mathrm{AaDO}_{2}\right)$ during the first 24 hours after birth in calves placed in the lateral and sternal positions and in those suspended by the hind legs immediately after delivery (mean \pm SEM). 
24 hours, calves suspended showed lowest $\mathrm{PaCO}_{2}$ values (Fig. 1).

From birth to 24 hours, $\mathrm{AaDO}_{2}$ decreased significantly ( $p \leq 0.001)$ with an initial sharp decrease during the first six hours followed by a plateau. $\mathrm{AaDO}_{2}$ was significantly $(p \leq 0.05)$ lower in calves in sternal recumbency and suspended by the hind legs than in those in lateral recumbency (Fig. 1).

At birth, apH values were higher in calves that were suspended than in other calves (Fig. 2). From birth to five minutes after delivery, apH values decreased reaching 7.25 in the 3 groups of calves. From 5 minutes to 24 hours, apH increased progressively to above 7.35 from 12 hours on the 3 groups of calves. During this period, i.e. from 5 minutes to 24 hours, calves that were suspended showed significantly $(p \leq 0.05)$ higher apH than other calves (Fig. 2). $\mathrm{aHCO}_{3}$ and $\mathrm{vHCO}_{3}$ were the highest in the calves in lateral recumbency and the lowest in the calves in sternal recumbency, with intermediate values in the calves suspended (Fig. 2). After an initial decrease during the first five minutes after birth, aBE remained stable. From 12 hours, aBE showed a significant increase ( $p \leq 0.001)$ to reach at 24 hours values similar to those obtained on umbilical blood (Fig. 2).

In all calves, changes in RT during the first day after birth were characterised by a sharp decrease during the first 6 hours and then a slight increase between 6 and 12 hours, stabilising around $38.6^{\circ} \mathrm{C}$ after 12 hours. RT was significantly higher in calves in sternal recumbency $(p \leq 0.05)$ than in calves in lateral but differences disappeared after 12 hours (Fig. 3).

Main differences in mHR due to body position were observed during the first 3 hours: mHR was significantly $(p \leq 0.05)$ lower in calves suspended than in calves in lateral recumbency (Fig. 3).
From 5 minutes to 24 hours, $\mathrm{R}_{\mathrm{L}}$ decreased significantly $(p \leq 0.001)$ with time in all calves (Fig. 4). The $\mathrm{R}_{\mathrm{L}}$ values in all calves showed a greater variability during the first hour after delivery than later. Differences in $\mathrm{R}_{\mathrm{L}}$ due to body position were observed but were not significant.

From 5 minutes to 24 hours, there was a progressive and significant $(p \leq 0.001)$ increase in $\mathrm{C}_{\mathrm{Ldyn}}$ with time in the three groups of calves (Fig. 4). The increase in $C_{L d y n}$ with time was greater in calves that were suspended than in calves in sternal recumbency from 5 minutes to 24 hours and than in calves in lateral during the first two hours (Fig. 4).

$\mathrm{V}_{\mathrm{T}}$ increased significantly ( $p \leq 0.001$ ) from birth to 24 hours in the three groups of calves (Fig. 4). Increases in $\mathrm{V}_{\mathrm{T}}$ with time were higher in calves who were suspended or in sternal recumbency than in calves in lateral.

$\mathrm{RBC}, \mathrm{Hb}$ and $\mathrm{Ht}$ decreased significantly $(p \leq 0.001)$ from 5 minutes to 24 hours after delivery in all calves (Fig. 5). RBC was significantly ( $p \leq 0.05$ ) higher (Fig. 5) and $\mathrm{Hb}$ tended to be higher in calves who were suspended than in other calves (Fig. 5). Trends were similar for Ht but the differences were not statistically significant.

From birth to 24 hours, TP and $\beta_{2} \gamma$ increased significantly $(p \leq 0.001)$ (Fig. 5). From 6 to 24 hours after delivery, calves suspended and in sternal showed significantly $(p \leq 0.05)$ higher TP and $\beta_{2} \gamma$ than calves in lateral recumbency (Fig. 5).

\section{DISCUSSION}

In the present study, Belgian White and Blue calves were delivered at term. As indicated by the time to reach spontaneous sternal recumbency, they were vital enough to overcome the stress of birth [40].

Body positioning immediately after delivery clearly influenced respiratory adaptation to 

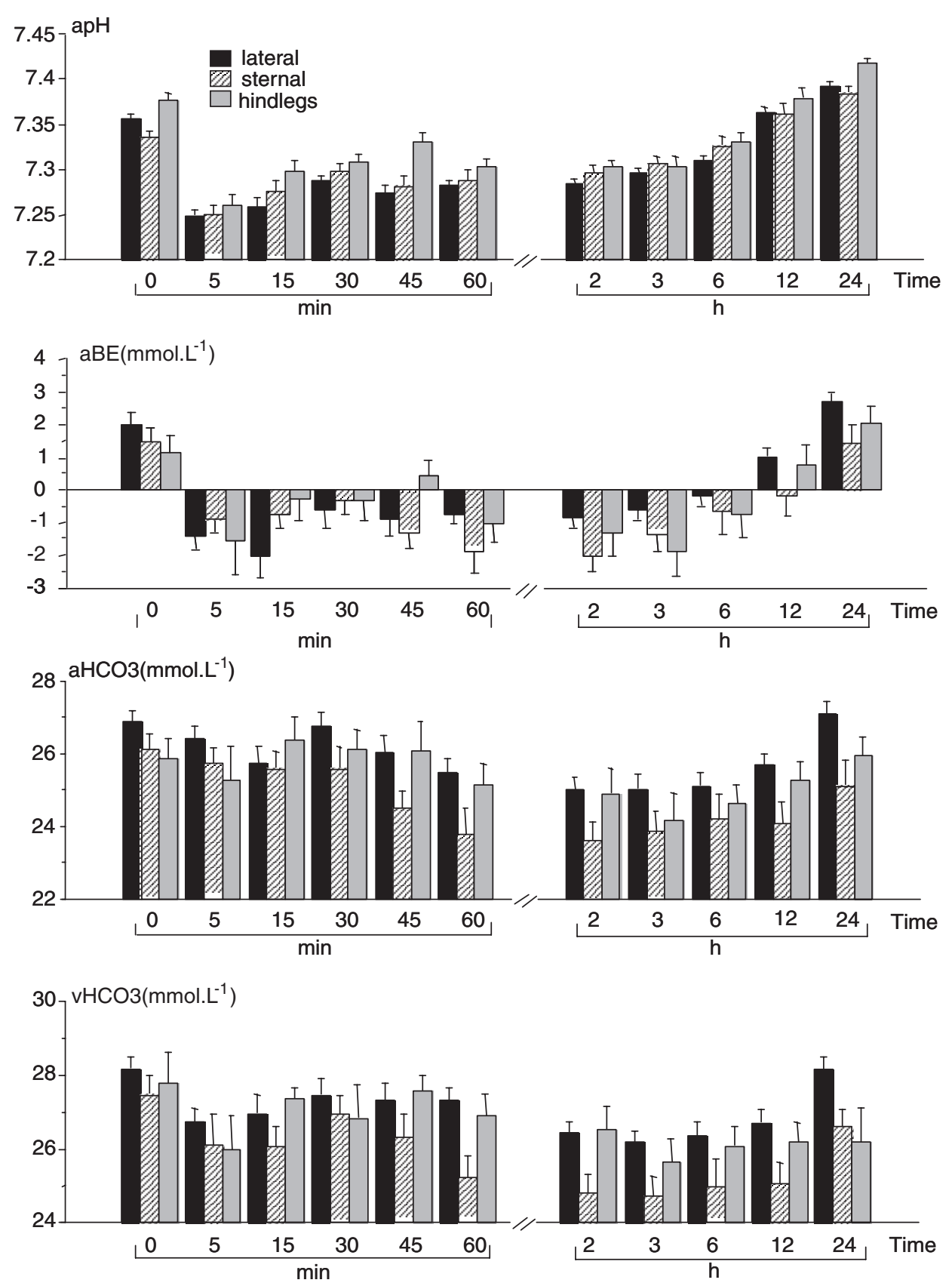

Figure 2. Changes in arterial $\mathrm{pH}(\mathrm{apH})$, arterial base excess (aBE), and arterial and venous bicarbonate concentrations $\left(\mathrm{aHCO}_{3}\right.$ and $\left.\mathrm{vHCO}_{3}\right)$ during the first 24 hours after birth in calves placed in the lateral and sternal positions and in those suspended by the hind legs immediately after delivery (mean \pm SEM). 

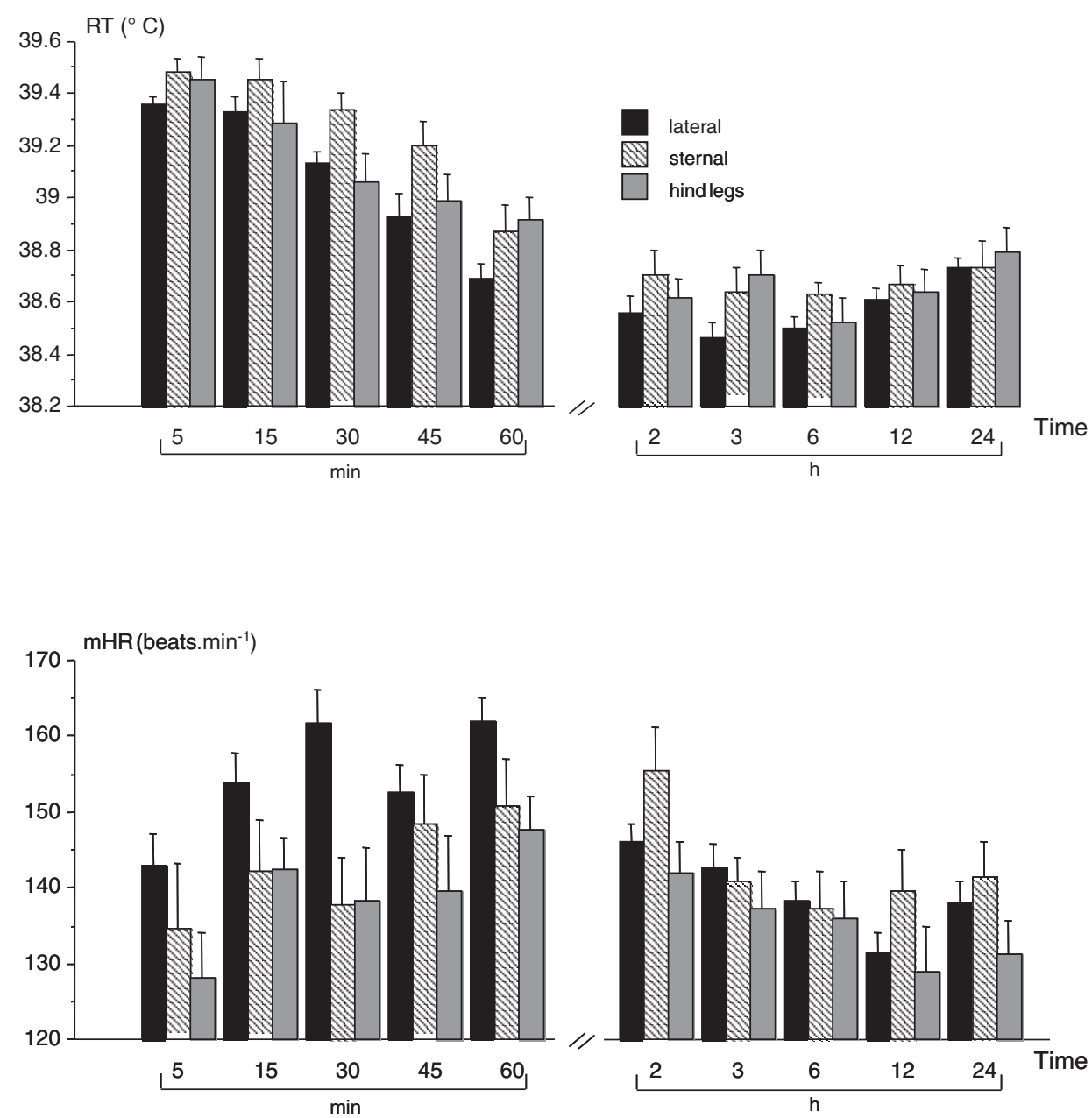

Figure 3. Changes in rectal temperature (RT) and heart rate (mHR) during the first 24 hours after birth in calves placed in the lateral and sternal positions and in those suspended by the hind legs immediately after delivery (mean \pm SEM).

extra-uterine life in healthy Belgian White and Blue calves delivered at term by an elective caesarean section.

Imposed sternal recumbency and suspension by the hind legs for less than 90 seconds $(75 \pm 5 \mathrm{~s})$ immediately after um- bilical cord rupture represent two nursing procedures which have a favourable impact on the efficiency of pulmonary gas exchanges as indicated by significantly higher $\mathrm{PaO}_{2}$ and $\mathrm{SaO}_{2}$ and lower $\mathrm{PaCO}_{2}$ in calves in these two positions than in calves left in lateral recumbency immediately after birth. 

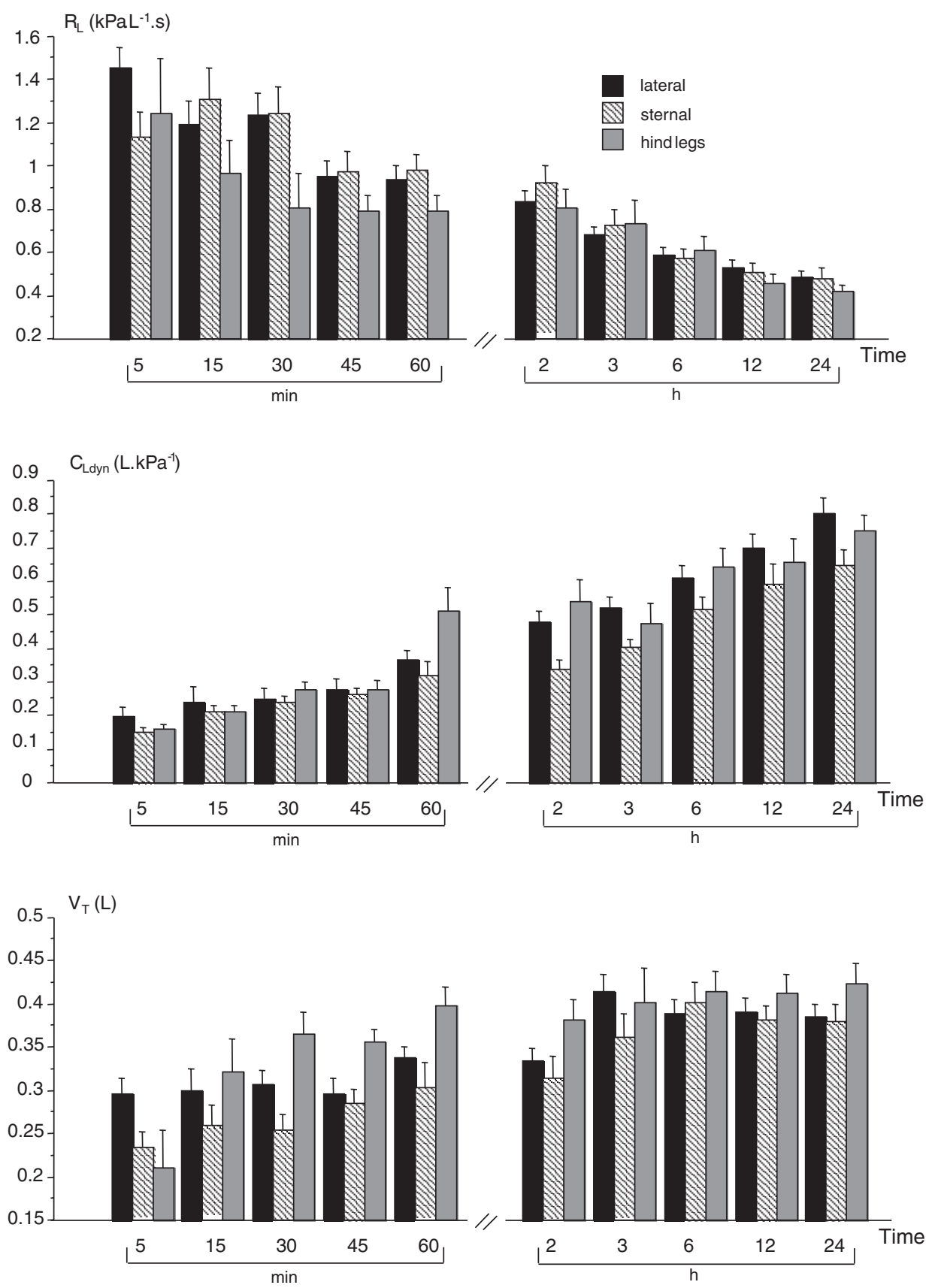

Figure 4. Changes in total pulmonary resistance $\left(R_{L}\right)$ in dynamic lung compliance $\left(C_{L d y n}\right)$ and in tidal volume $\left(\mathrm{V}_{\mathrm{T}}\right)$ during the first 24 hours after birth in calves placed in the lateral and sternal positions and in those suspended by the hind legs immediately after delivery (mean \pm SEM). 

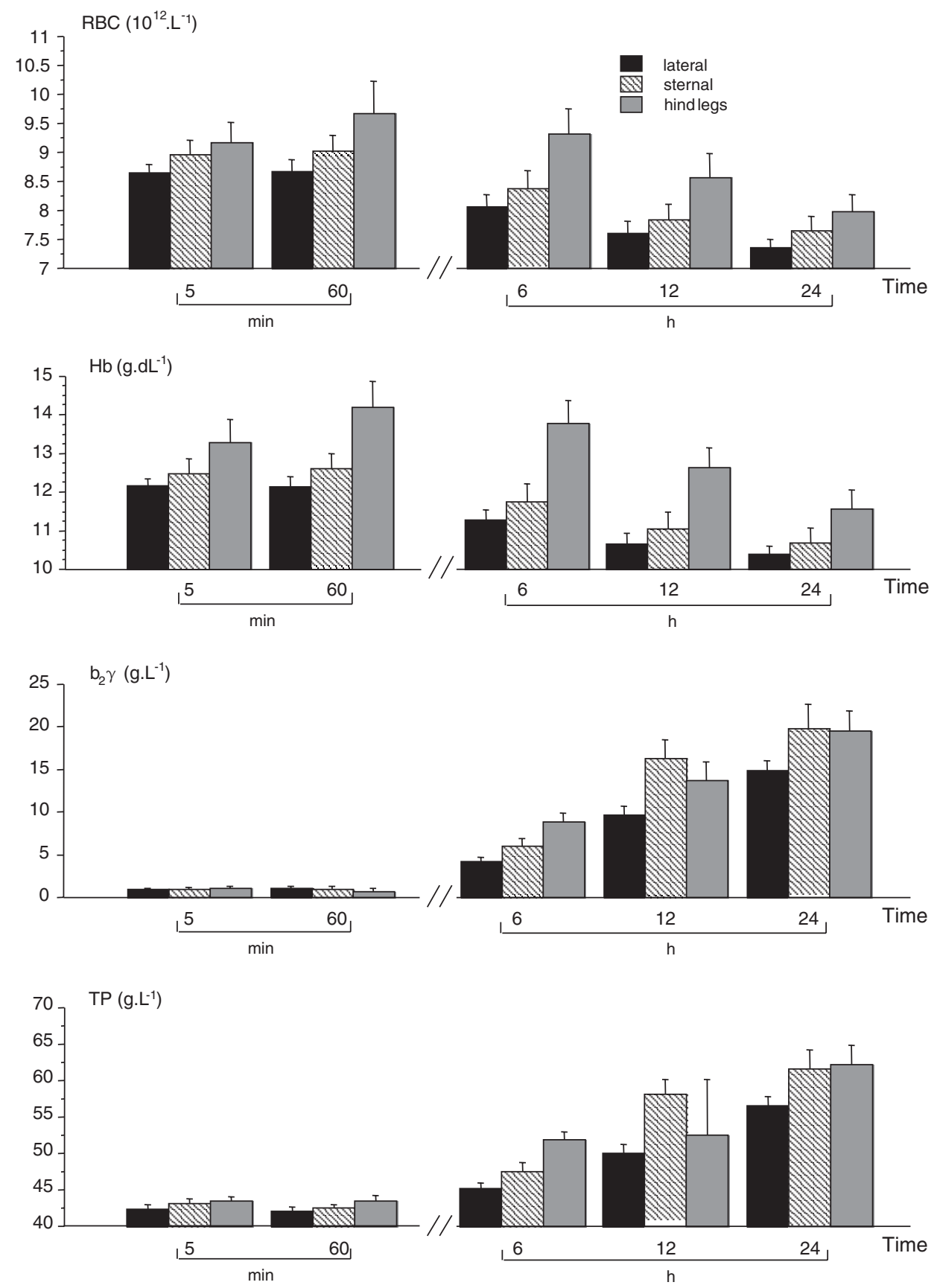

Figure 5. Changes in red blood cell count (RBC) in total haemoglobin concentration ( $\mathrm{Hb}$ ), serum $\beta_{2} \gamma$ globulin and total protein (TP) concentrations during the first 24 hours after birth in calves placed in the lateral and sternal positions and in those suspended by the hind legs immediately after delivery (mean \pm SEM). 
Significantly lower $\mathrm{AaDO}_{2}$ in calves in sternal recumbency or suspended by the hind legs suggest that these two body positions are associated either with better ventilationto-perfusion matching, or lower right-toleft shunting or better alveolo-capillar diffusion [47]. Moreover, the lower $\mathrm{PaCO}_{2}$ indicates that these two body positions also allow a better alveolar ventilation [9].

In humans, the following explanations have been proposed to explain the beneficial effect of the prone position (laid on the sternum) on oxygenation: there is a prone position-induced increase in functional residual capacity, change in regional diaphragm motion, and redistribution of perfusion [24].

A similar improvement in $\mathrm{PaO}_{2}$ with a change from the lateral to the sternal or the standing positions has been reported in foals [23, 27, 42] and adult anesthetised horses [17] and has been attributed to an improvement of alveolar ventilation, with or without a decrease of ventilation to perfusion mismatching and intrapulmonary or extrapulmonary (e.g. patent foramen ovale) right-to-left shunting [27].

Imposed sternal recumbency at birth also clearly influenced postnatal changes in ventilation and in pulmonary mechanics, probably related to changes in the shape of the chest wall, lung and diaphragm. Indeed, alterations in the shape of the chest wall distort the lung and affect regional ventilation [28].

Compared to calves in lateral recumbency, improved gas exchange in calves suspended by the hind legs probably result from a greater elimination of fetal lung fluid from upper and lower airways during suspension, as shown by the sharp decrease in $\mathrm{R}_{\mathrm{L}}$ and by the sharp increases in $\mathrm{V}_{\mathrm{T}}$ and $\mathrm{C}_{\mathrm{Ldyn}}$ observed in calves suspended at the first few pulmonary function test measurements [33]. Following these initial changes, the calves suspended by the hind legs at birth maintained lower $\mathrm{R}_{\mathrm{L}}$ and higher $\mathrm{V}_{\mathrm{T}}$ up to 24 hours and higher $\mathrm{C}_{\mathrm{Ldyn}}$ during the first 2 hours, indicating that the beneficial effect of suspension persisted.

Moreover, the significant increase in $\mathrm{PaO}_{2}, \mathrm{SaO}_{2}$ and $\mathrm{C}_{\mathrm{Ldyn}}$ and the significant decrease in $\mathrm{R}_{\mathrm{L}}$ that accompanied the increase in duration of the suspension suggest that the "longer" suspension allows better oxygenation due to the disappearance of both the upper and lower airway obstruction. Indeed, the elimination of fluid from the upper airways during suspension tended to be higher in the case of longer suspension but the relationship was not significant.

These results confirm that suspending the fetus upside down following delivery helps to drain aspirated fluid and that, in the case of an elective caesarean section, postnatal gas exchange is enhanced by a reduction in the volume of liquid remaining in the lungs when breathing starts [3].

Further studies should determine optimal duration of suspension and possible side-effects when too short or too long.

Body positioning immediately after delivery also influenced the postnatal acid-base balance in calves delivered by an elective caesarean section. Lower $\mathrm{aHCO}_{3}$, $\mathrm{vHCO}_{3}$ and $\mathrm{vBE}$ in calves in sternal or suspended than in calves in lateral accompanied by higher apH values indicate that they are able to compensate the greater metabolic acidosis related to these positions through a better alveolar ventilation and a higher ventilatory elimination of $\mathrm{CO}_{2}$ as indicated by their significantly lower $\mathrm{PaCO}_{2}$ [9].

Despite a similar body weight-related colostral intake within the first 6 hours, calves in sternal and suspended had significantly higher TP and $\beta_{2} \gamma$ from 6 to 24 hours than calves in lateral recumbency. Differences in TP and $\beta_{2} \gamma$ due to body position were probably caused by the increased absorption of colostral immunoglobulins because postnatal increases in TP and $\beta_{2} \gamma$ are 
markers of absorption of colostral immunoglobulins. This enhanced colostral passive transfer can be due to improved postnatal correction of hypoxaemia, hypercapnia and acidosis present at birth in calves in sternal and suspended than in calves in lateral recumbency. Indeed, it has been demonstrated that postnatal respiratory acidosis and hypoxaemia negatively affect colostral immunoglobulin absorption [4, 5, 44].

$\mathrm{RBC}, \mathrm{Hb}$ and $\mathrm{Ht}$ decreased with time during the first 24 hours after birth in all calves, but these values were the highest in calves suspended by the hind legs. Higher $\mathrm{RBC}, \mathrm{Hb}$ and $\mathrm{Ht}$ in the calves who were suspended than in the calves in lateral recumbency without concomitant higher albumin content suggest that these differences cannot be caused by hemoconcentration. It is unlikely that higher $\mathrm{RBC}, \mathrm{Hb}$ and $\mathrm{Ht}$ in suspended calves result from an increased erythropoiesis: higher RBC appeared early after birth, i.e. from 5 minutes, which is a delay largely insufficient for full erythropoiesis processes. Therefore, the explanation could be that RBC were released from spleen in response to "stress" due to suspension as indicated by slightly but not significant higher cortisol levels in suspended than in other calves [19].

Positional differences in heart rate and heart period variability have been reported in healthy preterm and term infants and have been attributed to variations in autonomic control [38]. Another explanation consists in a suspension-related increased arterial blood pressure which caused a reflex decrease in heart rate following a stimulation of baroreceptors located in the aortic arch and carotid sinuses.

Differences in RT observed in the present study, with lower RT in calves left in lateral recumbency at birth, could result from increased heat losses through conduction when covered with amniotic fluid and left in lateral recumbency for a few minutes immediately at birth [11]. Moreover, improved blood oxygenation in suspended and sternal calves may also have contributed to increased heat production and non shivering thermogenesis by affecting the central and sympathetic nervous systems [8].

Clinical implications. The most important practical implication is the favourable effect of sternal recumbency and suspension by the hind legs for less than $90 \mathrm{sec}-$ onds $(75 \pm 5 \mathrm{~s})$ on adaptation to extra uterine life in newborn calves delivered by an elective caesarean section.

The normal calf spontaneously assumes a sternal position within a few minutes of delivery [40]. Our study and that of Schuijt $\&$ Taverne [40] suggest that sternal recumbency may be an instinctive behavioural adaptation of posture which helps to correct the hypoxaemia, hypercapnia and acidosis present at birth [45], contributing in turn to an enhanced passive immune transfer.

To encourage cardiopulmonary efficiency, optimal gas exchange and maximal passive immune transfer in both healthy and compromised newborn calves, particularly when hypoxaemia is anticipated or observed, early positioning in a sternal position should be encouraged.

Suspension by the hind legs for less than 90 seconds immediately after rupture of the umbilical cord should be encouraged in calves delivered by an elective caesarean section because it partially mimics a "normal vaginal uncomplicated birth". Indeed, although the suspension does not create a thorax compression, it induces gas exchange disturbances during a short period of time, less than 90 seconds in the present study, because the umbilical cord is ruptured and spontaneous breathing is not yet present. The suspension also contributes to the elimination of fetal fluid from the upper airways.

Moreover, the significantly lower time to reach spontaneous sternal recumbency in suspended calves than in calves left in lateral indicates that suspension reduces the 
time required to reach spontaneous sternal recumbency which leads in turn to improved postnatal pulmonary gas exchange and correction of the mixed acidosis.

Further studies should evaluate the optimal duration of the suspension in order to have the most beneficial effects without side-effects. Further investigations are also required before systematic application of this procedure in calves who are in severe hypoxaemia, hypercapnia, and acidosis due to difficult parturition.

\section{ACKNOWLEDGEMENTS}

The authors are very grateful to Prof. F. Geubelle, Dr J. Detilleux and Dr B. Genicot for their advice, $\mathrm{Mr} \mathrm{O}$. Bonhiver, $\mathrm{Mr} \mathrm{M}$. Motkin, $\mathrm{Mr}$ J.-F. Rouelle, Mrs I. Sbaï for their technical assistance and to Mrs M. Leblond for the preparation of the manuscript. They are also grateful to Prof. L Istasse, Dr I. Dufrasnes, Mr and Mrs Jacoby, Dr L. Lunskens and Mr and Mrs Tilkin for active collaboration in the experiments and for daily care of the animals.

Financial support has been provided by the Federal Ministry of Agriculture of Belgium.

\section{REFERENCES}

[1] Adams R., Garry F.B., Aldridge B.M., Holland M.D., Odde K.G., Hematologic values in newborn beef calves, Am. J. Vet. Res. 53 (1992) 944-950.

[2] Akaike H., Information theory and an extension of the maximum likelihood principle, in: Second International Symposium of Inference Theory, Petrov B.N., Csàki F. (Eds.), Akadémiai Kiadó, Budapest, 1973, pp. 267-281.

[3] Berger P.J., Smolich J.J., Ramsden C.A., Walker A.M., Effect of lung liquid volume on respiratory performance after caesarean delivery in the lamb, J. Physiol. (Lond.) 492 (1996) 905-912.

[4] Besser T.E., Szenci O., Gay C.C., Decreased colostral immunoglobulin absorption in calves with postnatal respiratory acidosis, J. Am. Vet. Med. Assoc. 196 (1990) 1239-1243.

[5] Boyd J.W., Relationships between acid-base balance, serum composition and colostrum absorption in newborn calves, Br. Vet. J. 145 (1989) 249-256.
[6] Brunson D.B., Ventilatory support of the newborn calf, Compend. Contin. Educ. Pract. Vet. 3 (1981) S47-S52.

[7] Coghe J., Uystepruyst Ch., Bureau F., Detilleux J., Art T., Lekeux P., Validation and prognostic value of plasma lactate measurement in bovine respiratory disease, Vet. J. 160 (2000) 139-146.

[8] Comline R.S., Silver M., Development of activity in the adrenal medulla of the foetus and new-born animal, Br. Med. Bull. 22 (1966) 16-20.

[9] Davidson F.F., Glazier J.B., Murray J.F., The components of the alveolar-arterial oxygen tension difference in normal subjects and in patients with pneumonia and obstructive lung disease, Am. J. Med. 52 (1972) 754-762.

[10] De Kruif A., Benedictus G., Perinatal mortality and the birth of weak calves, Tijdschr. Diergeneeskd. 118 (1993) 684-688.

[11] Dechamps P., Nicks B., Exigences climatiques et modes de logement des veaux d'élevage, Ann. Méd. Vét. 128 (1984) 597-614.

[12] Detilleux J., Les carnets d'étable, Le Courrier du Cesam Mars, 2000, pp. 7-16.

[13] Dimitriou G., Greenough A., Castling D., Kavadia V., A comparison of supine and prone positioning in oxygen-dependent and convalescent premature infants, Br. J. Intensive Care 6 (1996) 254-259.

[14] Dobson A., Gleed R.D., Meyer R.E., Stewart B.J., Changes in blood flow distribution in equine lungs induced by anaesthesia, Q. J. Exp. Physiol. 70 (1985) 283-297.

[15] Esslemont R.J., Kossaibati M.A., Incidence of production diseases and other health problems in a group of dairy herds in England, Vet. Rec. 139 (1996) 486-490.

[16] Fisher E.W., Arterial puncture in cattle, Vet. Rec. 68 (1956) 691-692.

[17] Gleed R.D., Dobson A., Improvement in arterial oxygen tension with change in posture in anesthetised horses, Res. Vet. Sci. 44 (1988) 255-259.

[18] Harvey D., Desrochers A., Adaptations physiologiques, examen clinique et réanimation néonatale chez le veau, Med. Vet. Québec 19 (1989) 114-120.

[19] Hoyer C., Grunert E., Jöchle W., Plasma glucocorticoid concentrations in calves as an indicator of stress during parturition, Am. J. Vet. Res. 51 (1990) 1882-1884.

[20] Jones R.H., Longitudinal Data Analysis with Serial Correlation: A State-space Approach, Chapman and Hall, London, 1993.

[21] Kasari T.R., Weakness in neonatal calves associated with dystocia, Agri-Pract. 10 (1989) 19-25.

[22] Kelman G.R., Nunn J.F., Nomograms for correction of blood $\mathrm{P}_{\mathrm{O} 2}, \mathrm{C}_{\mathrm{O} 2}, \mathrm{pH}$ and base excess for 
time and temperature, J. Appl. Physiol. 21 (1966) 1484-1490.

[23] Kosch P.C., Koterba A.M., Coons T.J., Webb A.I., Developments in management of the newborn foal in respiratory distress. 1: Evaluation, Equine Vet. J. 16 (1984) 312-318.

[24] Lamm W.J., Graham M.M., Albert R.K., Mechanism by which the prone position improves oxygenation in acute lung injury, Am. J. Respir. Crit. Care Med. 150 (1994) 184-193.

[25] Lekeux P., Hajer R., Breukink H.J., Pulmonary function testing in calves: technical data, Am. J. Vet. Res. 45 (1984) 342-345.

[26] Lekeux P., Hajer R., Breukink H.J., Intrathoracic pressure measurement in cattle: standardized procedure, Can. J. Comp. Med. 48 (1984) 420-421.

[27] Madigan J.E., Thomas W.P., Backus K.Q., Powell W.E., Mixed venous blood gases in recumbent and upright positions in foals from birth to 14 days of age, Equine Vet. J. 24 (1992) 399-401.

[28] Margulies S.S., Rodarte J.R., Shape of the chest wall in the prone and supine anesthetized dog, J. Appl. Physiol. 68 (1990) 1970-1978.

[29] Massip A., Wouters-Ballman P., Beckers J.-F., Ectors F., Evolution du taux de cortisol plasmatique chez le veau de la naissance à l'âge de 14 jours, C. R. Acad. Sci., Paris, Sér. D 285 (1977) 563-565.

[30] Mee J.F., Resuscitation of newborn calves - materials and methods, Cattle Pract. 2 (1994) 197-210.

[31] Mee J.F., Stillbirths - What can you do ?, Cattle Pract. 7 (1999) 277-281.

[32] Mellor D.J., Integration of perinatal events, pathophysiological changes and consequences for the newborn lamb, Br. Vet. J. 144 (1988) 552-569.

[33] Mortola J.P., Dynamics of breathing in newborn mammals, Physiol. Rev. 67 (1987) 187-243.

[34] Patterson D.J., Bellows R.A., Burfening P.J., Carr J.B., Occurrence of neonatal and postnatal mortality in range beef cattle. I. Calf loss incidence from birth to weaning, backward and breech presentations and effects of calf loss on subsequent pregnancy rate of dams, Theriogenology 28 (1987) 557-571.

[35] Randall G.C.B., Perinatal mortality: some problems of adaptation at birth, Adv. Vet. Sci. Comp. Med. 22 (1978) 53-81.

[36] Roeder B.L., Schaalje G.B., Kelly E.J., Clark F.D., A rapid method for determination of blood glucose concentration in cattle, J. Am. Vet. Med. Assoc. 208 (1996) 707-710.
[37] Rossdale P.D., Advances in equine perinatology (1956-1996): a tribute, Equine Vet. Educ. 9 (1997) 273-277.

[38] Sahni R., Schulze K.F., Kashyap S., Ohira Kist K., Myers M.M., Fifer W.P., Body position, sleep states, and cardiorespiratory activity in developing low birth weight infants, Early Hum. Dev. 54 (1999) 197-206.

[39] Schuijt G., Iatrogenic fratures of ribs and vertebrae during delivery in perinatally dying calves: 235 cases (1978-1988), J. Am. Vet. Med. Assoc. 197 (1990) 1196-1201.

[40] Schuijt G., Taverne M.A.M., The interval between birth and sternal recumbency as an objective measure of the vitality of newborn calves, Vet. Rec. 135 (1994) 111-115.

[41] Skadberg B.T., Markestad T., Behaviour and physiological responses during prone and supine sleep in early infancy, Arch. Dis. Child. 76 (1997) 320-324.

[42] Stewart J.H., Rose R.J., Barko A.M., Respiratory studies in foals from birth to seven days old, Equine Vet. J. 16 (1984) 323-328.

[43] Szenci O., Taverne M.A.M., Bakonji S., Erbödi A., Comparison between pre- and postnatal acid-base status of calves and their perinatal mortality, Vet. Q. 10 (1988) 140-144.

[44] Tyler H., Ramsey H., Hypoxia in neonatal calves: effect on intestinal transport of immunoglobulins, J. Dairy Sci. 74 (1991) 1953-1956.

[45] Uystepruyst Ch., Reinhold P., Coghe J., Bureau F., Lekeux P., Mechanics of the respiratory system in healthy newborn calves using impulse oscillometry, Res. Vet. Sci. 68 (2000) 47-55.

[46] Vermorel M., Vernet J., Dardillat C., Saido, Demigne C., Energy metabolism and thermoregulation in the newborn calf. Variations during the first day of life and differences between breeds, Can. J. Anim. Sci. 69 (1989) 103-111.

[47] West J.B., Ventilation-perfusion relationships, Am. Rev. Respir. Dis. 116 (1977) 919-943.

[48] White K.R., Anderson D.M., Bate L.A., Increasing piglet survival through an improved farrowing management protocol, Can. J. Anim. Sci. 76 (1996) 491-495.

[49] Whitsett J.A., Stahlman M.T., Impact of advances in physiology, biochemistry, and molecular biology on pulmonary disease in neonates, Am. J. Respir. Crit. Care Med. 157 (1998) S67-S71.

[50] Wittum T.E., Perrino L.J., Passive immune status at postpartum hour 24 and long-term health and performance of calves, Am. J. Vet. Res. 56 (1995) 1149-1154. 